\title{
NOVEL SNP OF CALPAIN-1 (CAPN1) GENE AND ITS ASSOCIATION WITH CARCASS AND MEAT CHARACTERISTICS TRAITS IN BALI CATTLE
}

\author{
N. Pratiwi ${ }^{1}$, Maskur ${ }^{2}$, R. Priyanto ${ }^{3}$ and Jakaria $^{3}$ \\ ${ }^{1}$ Graduate School of Animal Science, Bogor Agricultural University, \\ Jl. Agatis, Darmaga Campus, Bogor 16680 - Indonesia \\ ${ }^{2}$ Faculty of Animal Science, Mataram University, \\ Jl. Majapahit No 62, Mataram 83125 - Indonesia \\ ${ }^{3}$ Faculty of Animal Science, Bogor Agricultural University, \\ Jl. Agatis, Darmaga Campus, Bogor 16680 - Indonesia \\ CorrespondingE-mail: jakaria_karman@yahoo.co.id \\ Received June 22, 2016; Accepted August 05, 2016
}

\begin{abstract}
ABSTRAK
Gen kalpain-1 (CAPN1) adalah salah satu gen yang menghasilkan enzim kalpain yang mengontrol struktur protein daging dan keempukan. Tujuan dari penelitian ini adalah untuk mengidentifikasi Single Nucleotide Polymorphism (SNP) pada gen CAPN1 ekson 5-6 dan asosiasinya terhadap karakteristik karkas dan daging pada sapi bali. Sapi bali yang digunakan sebanyak 48 ekor yang dipelihara di BPTUHMT Sapi Bali, Provinsi Bali. Keragaman SNP gen CAPN1 ekson 5-6 diidentifikasi dengan metode direct sequencing dengan menggunakan program MEGA 5. Frekuensi alel dan genotipe, juga keseimbangan Hardy-Weinberg dianalisis menggunakan program PopGen 1.32. Asosiasi keragaman genotipe (SNP) gen CAPN1 dengan karakteristik karkas dan daging dianalisis menggunakana metode Generalized Linear Model (GLM) dengan program SAS. Hasil penelitian menunjukkan bahwa ditemukan sebanyak 8 SNP yaitu c.3669T $>$ C, c.3854G $>$ A, c.3881T $>C$, c.3899C $>$ T, с.3908C $>\mathrm{G}$, c. $4002 \mathrm{C}>\mathrm{A}, \mathrm{c} .4021 \mathrm{G}>\mathrm{T}$ dan c. $4037 \mathrm{~A}>\mathrm{C}$ di fragmen gen CAPN1 ekson 5-6 bersifat polimorfik pada sapi bali. Asosiasi keragaman SNP c.3669T $>$ C, c.3854G $>$ A dan c.3899C $>$ T nyata $(\mathrm{P}<0.05)$ pengaruhnya terhadap rump thickness (RT), rump fat thickness (RFT) dan marbling score (MS), sedangkan SNP c. $4037 \mathrm{~A}>\mathrm{C}$ tidak nyata pengaruhnya terhadap karakteristik karkas dan daging. SNP yang asosiasinya nyata terhadap karakteristik karkas dan daging yaitu SNP c.3669T $>$ C, c.3854G $>$ A dan c.3899C $>$ T dapat dijadikan sebagai kandidat Marker Assisted Selection (MAS) pada sapi bali.
\end{abstract}

Kata kunci: sapi bali, gen CAPN1, SNP

\begin{abstract}
Calpain-1 gene (CAPN1) produces an calpain enzyme controlling structure of meat protein and tenderness. The aims of this study were to identify Single Nucleotide Polymorphism (SNP) in exon 5 and 6 of CAPN1 gene and its associate with carcass and meat characteristic traits in bali cattle. A total of 48 bali cattles from BPTU-HMT Bali Cattle, Bali Province were used in the research. SNP in exon 5 and 6 of CAPN1 gene were identify with direct sequencing using MEGA 5 program. Analysis of polymorphism was conducted by PopGen 1.32 software to identify frequencies of genotype, allele and Hardy-Weinberg equilibrium. The association of CAPN1 gene genotype with carcass and meat characteristic traits was analyzed using Generalized Linear Model (GLM) procedure of SAS. Sequencing analysis at exon 5-6 of CAPN1 gene in Bali cattle resulted in eight polymorphic SNPs. They are c.3669T $>\mathrm{C}, \quad$ c. $3854 \mathrm{G}>\mathrm{A}, \quad$ c. $3881 \mathrm{~T}>\mathrm{C}, \quad$ c. $3899 \mathrm{C}>\mathrm{T}, \quad$ c. $3908 \mathrm{C}>\mathrm{G}, \quad$ c. $4002 \mathrm{C}>\mathrm{A}, \quad$ c. $4021 \mathrm{G}>\mathrm{T}$ and
\end{abstract}


c.4037A $>$ C. The SNPs c.3669T $>$ C, c.3854G $>$ A and c.3899C $>$ T were significantly $(\mathrm{P}<0.05)$ associated with rump thickness (RT), rump fat thickness (RFT) and marbling score (MS), while SNP c.4037A $>C$ was not significantly associated with carcass and meat characteristic traits. The SNPs were significantly associated with carcass and meat characteristic traits namely c.3669T $>C$, c.3854G $>$ A and c.3899C $>$ T. Those SNPs may be used as candidate marker for Marker Assisted Selection (MAS) in bali cattle.

Keywords: Bali cattle, CAPN1 gene, SNP

\section{INTRODUCTION}

Bali cattle population in Indonesia contributes approximately $32.31 \%$ of 14.8 million heads national cattle population (PSPK, 2011). Meat production in Indonesia has risen about 2.5 $\%$ (435 086 - 446180 tons), followed by meat consumption increasing about $7.8 \%$ (593 516 639857 tons) (BPS, 2014). Bali cattle is Indonesian origin cattle that has been domesticated from banteng (Martojo, 2003) and has admited by FAO as a breed in the world. Bali cattle has contribution to fulfill meat demand in Indonesia about 27\% (Purwantara et al., 2012). Bali cattle has abilty to survive in marjinal feed condition (Purwantara et al., 2012) and environment (Talib, 2002), has high abilty in reproduction, has high carcass percentage (Melendez dan Marchelo, 2014) and also has good meat quality (Bugiwati, 2007).

The good quality of bali cattle's meat has not been optimized. Selection can be used to improve bali cattle's meat quality (Bourdon, 2000) using Marker Assisted Selection (MAS) (Soller, 1994; Schwerin et al., 1995). MAS method has been widely applied in animals (Li et al., 2010). One of many genes used in MAS method is CAPN1 gene that control carcass and meat characteristic traits (Xu and Mellgren, 2002; Hou et al., 2011). In other case CAPN1 also controls tenderness (Goll et al., 1992; Killerfer et al., 1994; Azari et al., 2012).

CAPN1 gene is located in cromosome 29 (Casas et al., 2005; Pinto et al., 2010) and consists of 21 exon and 20 intron (Dear et al., 2000). There are some studies related CAPN1 in chicken (Zhang et al., 2007; Felicio et al., 2012), some cattles such as brahman (Casas et al., 2005), nellore (Pinto et al., 2010), angus, charolais, hereford, limuosin, simmental (Li et al., 2013), luxi, jinnan, qinchuan, simmental x menggu (Hou et al., 2011), sheep (Azari et al., 2012), swine (Gandolfi et al., 2011). It provides that CAPN1 has been studied in many animals but not for bali cattle. The objective of the study were to identify Single Nucleotide Polymorphism (SNPs) in exon
5 and 6 of CAPN1 gene and associate with carcass and meat characteristic traits in bali cattle. This is the first study that provides CAPN1 gene analysis in bali cattle.

\section{MATERIALS AND METHODS}

\section{Animals}

A total 48 heads sample of bali cattle consist of 24 heifers and 24 streers that were raised in same paddock from BPTU-HMT Bali Cattle Denpasar, Bali Province. Data were collected at 12-15 months of age. The bali cattle was breed an extensive cattle-raising system and was fed grasses in the amount of $10 \%$ (Pennisetum purpureum and Phaspalum notatum) and feed concentrate as much as $1 \%$ of body weight, also ad libitum drinking method.

\section{DNA Extraction}

DNA was extracted using DNA kit GeneAid method that consisted of sample preparation, lysis sel, DNA binding, wash and DNA elution. The quality of total genome extractions was performed by $1 \%$ agarose gel electrophoresis and was checked by spectrophotometry.

\section{Amplification}

Amplification fragment of CAPN1 gene in exon 5-6 was analyzed using thermo cycler Eppendorf machine with primer forward 5' CCG AGG GAT CTC AAA GCA G 3' and reverse 5' TGG GCT GAG TAG AGA GAA GG 3' (Hou et al., 2011) with length of Polymerase Chain Reaction (PCR) product was 498 bp. PCR reaction was carried out in $50 \mu 1$ consisted DNA template $(1 \mu 1)$, PROMEGA Green Master Mix $(25 \mu 1)$, Nuclease Free Water $(23.6 \mu 1)$, primer forward $(0.2 \mu \mathrm{l})$ and reverse $(0.2 \mu \mathrm{l})$. Amplification condition consisted of predenaturasi at $95^{\circ} \mathrm{C}(5 \mathrm{~min}), 35$ cycles (denaturation at $95^{\circ} \mathrm{C}(10 \mathrm{sec})$, annealing $61^{\circ} \mathrm{C}$ $(20 \mathrm{sec})$ and extension $72^{\circ} \mathrm{C}(30 \mathrm{sec})$. PCR products were electrophoresed using $1.5 \%$ agarose gel. 


\section{Sequences Analysis}

PCR products of CAPN1 gene in bali cattle were sequenced using the $1^{\text {st }}$ Base sequencing company, Selangor, Malaysia. Forward and reverse primer fragments were sequenced using ABI Prims 3100-Avant Genetic Analyzer sequencer machine.

\section{Data Analysis}

The carcass characteristic traits analyzed in bali cattle were longissimus dorsi thickness (LDT), back fat thickness (BFT), rump thickness (URT), rump fat thickness (RFT). The measurement of LTD and BFT were performed on the $12^{\text {th }}-13^{\text {th }}$ (Ulum et al. 2014) that is presented in Figure 1. The measurement of RT and RFT were measured between ileum and ischium (Silva et al., 2012). The meat characteristic traits analyzed in bali cattle were marbling score (MS) and intra muscular fat percentage (PIMF). The carcass and meat characteristic traits measurement have been done using Veterinary Ultrasound Scanner WED-3000V having frequency $6.5 \mathrm{~Hz}$ and scaning we conducted at $130 \mathrm{~mm}$ in deep. The ultrasound image scaning were analyzed using Image-J NIH software (Image J ${ }^{\circledR}$, NIH, USA) (Figure 2). The marbling score carried out according to AUSTRALIAN MEAT and MSA marbling reference standard (http://www. wagyu.org.au/marbling/) and intra muscular fat percentage (PIMF) based on Deaton and Rause (2000). The sequencing results were aligned using Bio Edit (Hall, 1999) and SNPs were identified using MEGA software with alignment clustalW method (Tamura et al., 2011). Frequenceies of genotype and allele, Hardy-Weinberg equilibrium were calculated using PopGene 1.32 program (Raymond and Rousset., 2001). The associations between CAPN1 gene with carcass and meat characteristic traits were analyzed using ANCOVA PROC GLM procedure of SAS (2008). The statistical model used was:

$$
\mathrm{Y}_{\mathrm{ijk}}=\mu+\alpha_{\mathrm{i}}+\beta_{\mathrm{j}}+\gamma \mathrm{X}_{\mathrm{k}}+\varepsilon_{\mathrm{ijk}}
$$

Where $Y_{i j k}$ is the mean value of the trait; $\mu$ is the general mean; $\alpha_{i}$ is the fixed effect of CAPN1

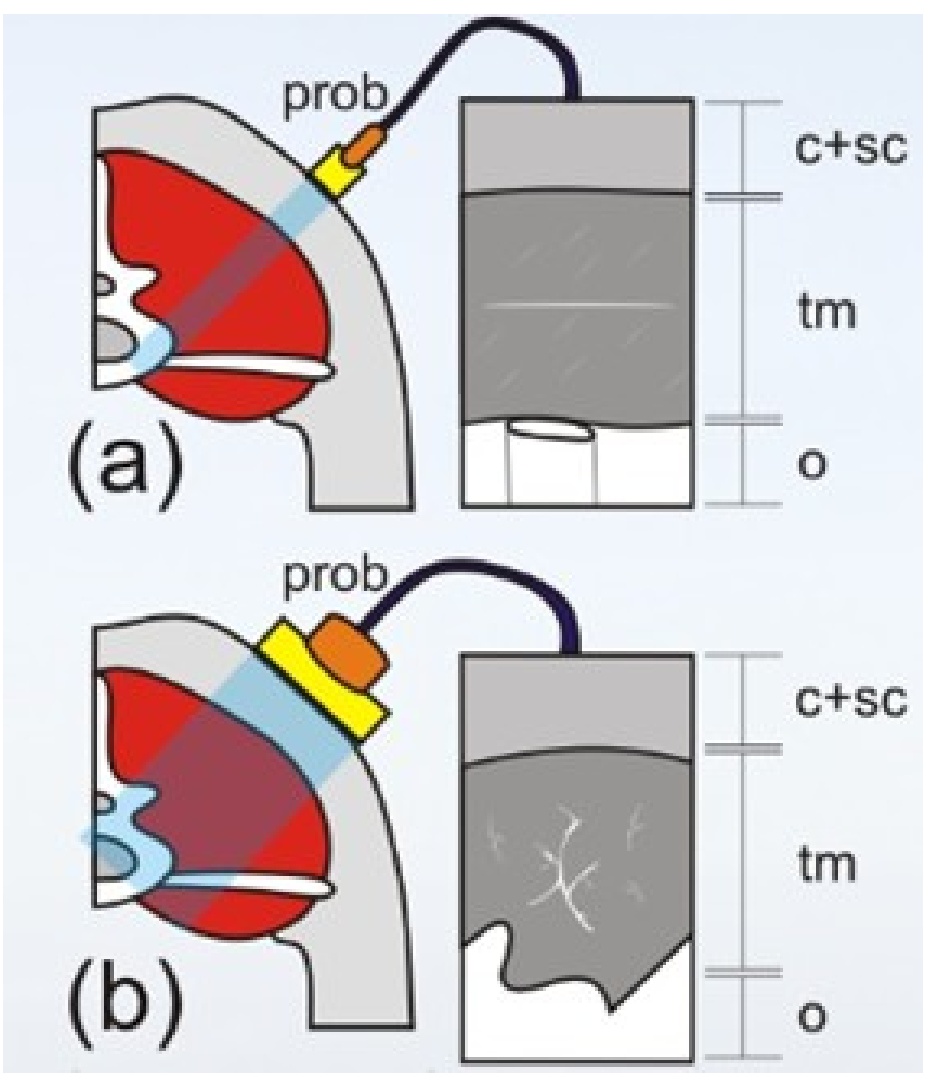

Figure 1. Illustration ultrasound longissimus dorsi in cattle, (a) horizontally (b) vertically, c = cutan, sc $=$ subcutan, $\mathrm{tm}=$ thick muscle, $\mathrm{o}=$ bone. Source; Ulum et al. (2014). 

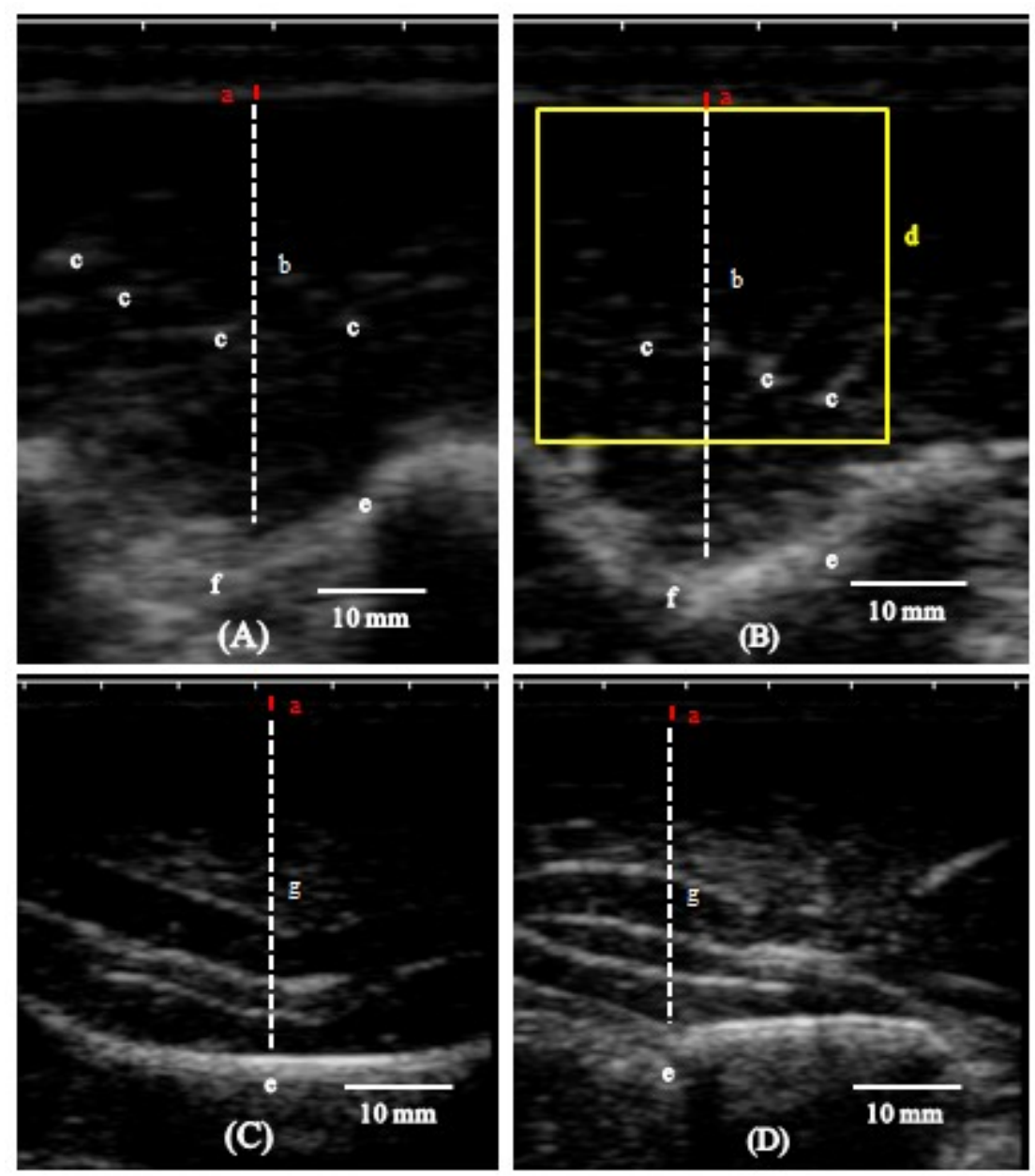

Figure 2. Ultrasound of Muscling Traits; (A) and (B) longissimus dorsi at $12^{\text {th }}-13^{\text {th }}$ rib horizontally and vertically measurement; (C) and (D) rump thickness horizontally and vertically measurement; (a) BFT, (b) LDT, (c) intramusclar fat, (d) region of interest of PIMF, (d) bone, (f) rib (g) rump thickness

genotype $(i=1,2,3) ; \beta_{\mathrm{j}}$ is the fixed effect of sex $(\mathrm{j}=1,2) ; \gamma_{\mathrm{k}}$ is fix effect of ages; $\mathrm{X}$ is the regression $\mathrm{c}$.

\section{RESULTS AND DISCUSSION}

\section{Genetic Variablity and SNP Detection in CAPN1 Gene}

Alignment of DNA sequence for CAPN1 gene in exon 5-6 in bali cattle was amplified using PCR method with length of PCR product $498 \mathrm{bp}$ (Figure 3). Sequencing analysis in exon 5-6 of CAPN1 gene in Bali cattle resulted eight polymorphic SNPS. They are c.3669T $>C$, c. $3854 \mathrm{G}>\mathrm{A}$, c. $3881 \mathrm{~T}>\mathrm{C}$, c. $3899 \mathrm{C}>\mathrm{T}$, c $.3908 \mathrm{C}>\mathrm{G}$, c. $4002 \mathrm{C}>\mathrm{A}$, c. $4021 \mathrm{G}>\mathrm{T}$ and c. $4037 \mathrm{~A}>\mathrm{C}$ (Table 1). The SNPs in this research was polymorphic that were represented by allele frequency $\geq 0.01$ (Nei and Kumar, 2000). The highest allele frequency found in SNP c.3908 $\mathrm{C}>\mathrm{G}$ (0.99). CAPN1 gene polymorphism $\mathrm{A} / \mathrm{C}$ in Nellore cattle also performed by Pinto et al., (2010) having genotype frequency A (0.66) and C (0.34). The eight polymorphic SNPs of CAPN1 gene were caused by transition mutation at c.3908C $>\mathrm{G}$, c. $4021 \mathrm{G}>\mathrm{T}$ and transversion mutation at c. $3669 \mathrm{~T}>\mathrm{C}$, c. $3854 \mathrm{G}>\mathrm{A}$, c. $3881 \mathrm{~T}>\mathrm{C}$ c. $3899 \mathrm{C}>\mathrm{T}$, c. $4002 \mathrm{C}>\mathrm{A}$, c. $4037 \mathrm{~A}>\mathrm{C}$. Allendrof et al., 2013 explained that transition is nucleotide mutation purine to purine $(\mathrm{A}>\mathrm{T}$ or $\mathrm{T}>\mathrm{A})$ or pyrimidine to pyrimidine $(C>G$ or $G>C)$, however transversion is nucleotide mutation purine to pyrimidine $(\mathrm{A}>\mathrm{C}$ or $\mathrm{C}>\mathrm{A}, \mathrm{T}>\mathrm{G}$ or $\mathrm{G}>\mathrm{T})$ or pyrimidine to purine $(\mathrm{C}>\mathrm{A}$ or $\mathrm{A}>\mathrm{C})$. Li et al. (2013) in c.947 point found mutation $\mathrm{C} / \mathrm{G}$ in Angus, Charolais, 


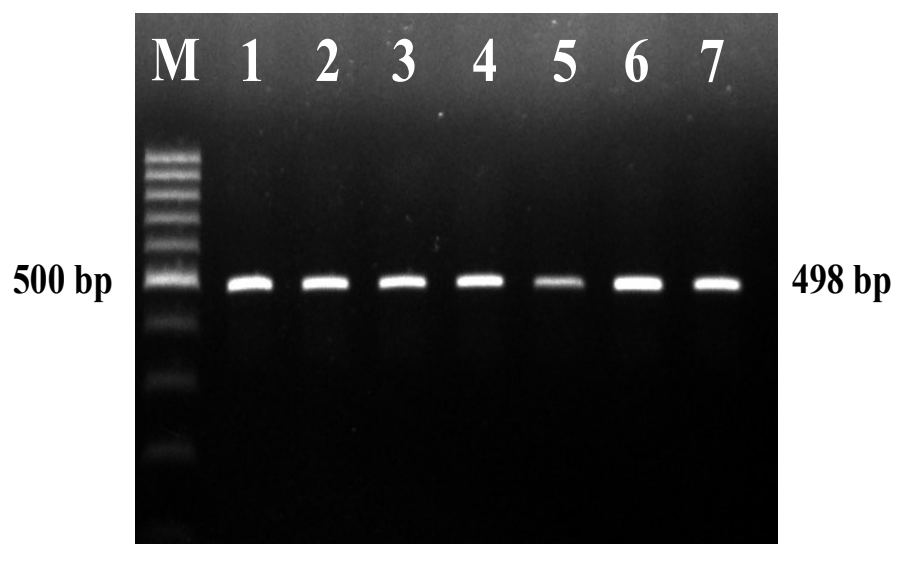

Figure 3. Amplification CAPN1 Gene in Bali Cattle (line 1-7; 489 bp); M: 100bp ladder

Table 1. Genetic Variability of CAPN1 Gene in Bali Cattle

\begin{tabular}{|c|c|c|c|c|c|c|}
\hline SNP & \multicolumn{3}{|c|}{ Frequency of Genotype } & \multicolumn{2}{|c|}{ Frequency of Allele } & $\chi^{2}$ \\
\hline \multirow{2}{*}{ c.3669 T $>C$} & TT & $\mathrm{CT}$ & $\mathrm{CC}$ & $\mathrm{C}$ & $\mathrm{T}$ & ns \\
\hline & 0.71 & 0.27 & 0.02 & 0.16 & 0.84 & \\
\hline \multirow{2}{*}{ c. $3854 \mathrm{G}>\mathrm{A}$} & GG & GA & AA & $\mathrm{G}$ & A & ns \\
\hline & - & 0.15 & 0.85 & 0.07 & 0.93 & \\
\hline \multirow{2}{*}{ c. $3881 \mathrm{~T}>\mathrm{C}$} & TT & $\mathrm{TC}$ & $\mathrm{CC}$ & $\mathrm{T}$ & $\mathrm{C}$ & ns \\
\hline & - & 0.06 & 0.94 & 0.03 & 0.97 & \\
\hline \multirow{2}{*}{ c. $3899 \mathrm{C}>\mathrm{T}$} & $\mathrm{CC}$ & $\mathrm{CT}$ & $\mathrm{TT}$ & $\mathrm{C}$ & $\mathrm{T}$ & ns \\
\hline & 0.85 & 015 & - & 0.93 & 0.07 & \\
\hline \multirow{2}{*}{ c. $3908 \mathrm{C}>\mathrm{G}$} & $\mathrm{CC}$ & $\mathrm{CG}$ & GG & $\mathrm{C}$ & $\mathrm{G}$ & ns \\
\hline & - & 0.02 & 0.98 & 0.01 & 0.99 & \\
\hline \multirow{2}{*}{ c. $4002 \mathrm{C}>\mathrm{A}$} & $\mathrm{CC}$ & $\mathrm{CA}$ & AA & $\mathrm{C}$ & $\mathrm{A}$ & $*$ \\
\hline & 0.96 & - & 0.04 & 0.96 & 0.04 & \\
\hline \multirow{2}{*}{ c. $4021 \mathrm{G}>\mathrm{T}$} & GG & GT & $\mathrm{TT}$ & $\mathrm{G}$ & $\mathrm{T}$ & $*$ \\
\hline & 0.98 & - & 0.02 & 0.98 & 0.02 & \\
\hline \multirow{2}{*}{ c. $4037 \mathrm{~A}>\mathrm{C}$} & AA & $\mathrm{AC}$ & $\mathrm{CC}$ & $\mathrm{A}$ & $\mathrm{C}$ & $*$ \\
\hline & 0.71 & - & 0.29 & 0.71 & 0.29 & \\
\hline
\end{tabular}

$\chi^{2}=$ Hardy-Weinberg equilibrium, $n s=$ not significant, $(*)$ significant at $\alpha 5 \%\left(\chi^{2}\right.$ obs $\left.\geq 3.84\right), n=48$ heads.

hereford, limousin, simmental. Among those cattle GG genotype was found higher than CC genotype.

Based on chi-square analysis $\left(\chi^{2}\right)$, five SNPs (c.3669T $>$ C, c.3854G $>$ A, c.3881T $>$ C, c.3899C $>$ T, and c.3908C $>\mathrm{G}$ ) were in Hardy-Weinberg equilibrium of CAPN1 gene in bali cattle and 3 SNPs (c.4002C $>$ A, c. $4021 \mathrm{G}>\mathrm{T}$, c. $4037 \mathrm{~A}>\mathrm{C}$ ) was not in Hardy-Weinberg equilibrium. Noor (2010) explained that genetic equilibrium in population 
was influenced by several factors such as nonrandom mating, selection, mutation, migration and genetic drift. We assumed that disequilibrium in bali cattle afffected by selection and nonrandom mating because production of bali cattle in BPTU-HMT, Bali Province aming to produce superior cattle.

\section{Association CAPN1 Gene with Carcass and Meat Characteristic Traits}

Correlation between SNPs and carcass and meat characteristic traits was analyzed in four points of eight polymorhic SNPs. These points are c. $3669 \mathrm{~T}>\mathrm{C}, \quad$ c. $3854 \mathrm{G}>\mathrm{A}, \quad$ c. $3899 \mathrm{C}>\mathrm{T}, \quad$ and c. $3908 \mathrm{C}>\mathrm{G}$. Three polymorphic SNPs (c.3669T $>$ C,$\quad$ c.3854G $>$ A, c.3899C $>$ T) were significantly $(\mathrm{P}<0.05)$ associated with carcass and meat characteristic traits (Table 2). A SNP c.3669T $>C$ associated with rump thickness (RT) and marbling score (MS), c.3854G $>$ A to rump fat thickness (RFT) and c.3899C $>$ T to marbling score (MS). Hou et al., (2011) explained that CAPN1 gene associated with marbling score (MS) in angus, simmental, jinnan, qinchuan, simmental $\mathrm{x}$ menggu cattle. Pinto et al, 2010 showed that CAPN1 gene (CAPN4753) having association with tenderness of longissimus dorsi muscle in Bos Indicus and Bos Taurus cattle. CAPN1 influences in meat tenderness by degrade myofibrillar protein in muscle afected muscle tenderness. Moreover association CAPN1 gene with carcass quality (cold carcass weight (CW) and marbling score (MS)) in hanwoo cattle (Cheong et al.,2008). Furthermore the higher of CAPN1 gene expression, the higher it's tenderness (te Pas et al., 2004). These associations may be used as candidate marker for MAS, so that the improvement of genetic quality can be more accurate, effective and efficient in bali cattle.

\section{CONCLUSION}

CAPN1 gene exon 5-6 in Bali cattle resulted in eight polymorphic SNPs. Three SNPs associated with carcass and meat characteristic traits. A SNP c.3669T $>$ C associated with rump thickness (RT) and marbling score (MS), c.3854G $>$ A associated with rump fat thickness (RFT) and c.3899C $>\mathrm{T}$ associated with marbling score (MS). The SNPs significantly associated with carcass and meat characteristic traits may be used as candidate marker for MAS in bali cattle.

\section{ACKNOWLEDGMENTS}

Authors thank to Ministry of Research and Technology for the financial support of the National Synergy Incentive Research (InSinas)

Table 2. Association of CAPN1 SNPs with Carcass and Meat Characteristic Traits in Bali Cattle

\begin{tabular}{|c|c|c|c|c|c|c|c|c|}
\hline \multirow[b]{2}{*}{ SNPs } & \multirow[b]{2}{*}{ Genotype } & \multirow[b]{2}{*}{$\mathrm{N}$} & \multicolumn{4}{|c|}{ Carcass Characteristic } & \multicolumn{2}{|c|}{ Meat Characteristics } \\
\hline & & & TLD (mm) & $\mathrm{BFT}(\mathrm{mm})$ & RT (mm) & RFT (mm) & $\begin{array}{c}\text { MS } \\
\text { (score) }\end{array}$ & PIMF (\%) \\
\hline \multirow[b]{2}{*}{ c. $3669 \mathrm{~T}>\mathrm{C}$} & & 8 & & $1.38=$ & & & $1.37 \pm 0.41^{\mathrm{a}}$ & $2.40 \pm 0.75$ \\
\hline & $\mathrm{TT}$ & 22 & $33.47 \pm 0.68$ & $1.50 \pm 0.07$ & $41.20 \pm 0.64^{\mathrm{b}}$ & $1.12 \pm 0.07$ & $2.59 \pm 0.23^{b}$ & $4.17 \pm 0.43$ \\
\hline \multirow[b]{2}{*}{ c. $3854 \mathrm{G}>\mathrm{A}$} & AA & 24 & $33.33 \pm 0.68$ & $1.53 \pm 0.06$ & $40.40 \pm 0.74$ & $1.15 \pm 0.06^{\mathrm{a}}$ & $2.37 \pm 0.25$ & $4.00 \pm 0.44$ \\
\hline & $\mathrm{AG}$ & 6 & $33.18 \pm 1.37$ & $1.23 \pm 0.13$ & $39.67 \pm 1.48$ & & $1.94 \pm 0.51$ & $2.70 \pm 0.88$ \\
\hline \multirow{2}{*}{ c. $3899 \mathrm{C}>\mathrm{T}$} & $\mathrm{CC}$ & 27 & $33.53 \pm 0.61$ & $1.47 \pm 0.06$ & $40.55 \pm 0.65$ & $1.09 \pm 0.06$ & $2.44 \pm 0.22^{\mathrm{a}}$ & $3.90 \pm 0.41$ \\
\hline & $\mathrm{CT}$ & 3 & $30.92 \pm 1.97$ & $1.40 \pm 0.21$ & $37.12 \pm 2.10$ & & $0.70 \pm 0.69^{b}$ & $1.98 \pm 1.30$ \\
\hline \multirow{2}{*}{ c. $4037 \mathrm{~A}>\mathrm{C}$} & AA & 24 & $33.47 \pm 0.67$ & $1.50 \pm 0.06$ & $40.56 \pm 0.72$ & $1.09 \pm 0.07$ & $2.31 \pm 0.25$ & $3.62 \pm 0.45$ \\
\hline & $\mathrm{CC}$ & 6 & $32.64 \pm 1.34$ & $1.33 \pm 0.13$ & $38.99 \pm 1.44$ & $1.02 \pm 0.14$ & $2.16 \pm 0.51$ & $4.12 \pm 0.89$ \\
\hline
\end{tabular}

a,b means with superscript different $(\mathrm{P}<0.05)$, longissimus dorsi thickness (LDT), back fat thickness $(\mathrm{BFT})$, rump thickness (URT), rump fat thickness (RFT), marbling score (MS) carried out according to AUSTRALIAN MEAT and MSA marbling reference standard (http://www.wagyu.org.au/marbling/) and intra muscular fat percentage (PIMF). 
with the contract number 12/SEK/INSINAS/PPK/IV/2015.

\section{REFERENCES}

Allendrof, F.W., G. Luikart and S.N. Aitken. 2013. Conservation and the genetics of populations. $2^{\text {nd }}$ Ed. Wiley-Blackwell Publishing. Chicester. UK.

Azari, M.A., E. Dehnavi, S. Yousefi and Shahmohamadi. 2012. Polymorphism of calpastatin, calpain, and myostatin gene in native dalagh sheep in Iran. Slovak. J. Anim. Sci. 45(1): 1-6.

[BPS] Badan Pusat Statistik. 2011. Pendataan Sapi Potong, Sapi Perah, dan Kerbau 2011 (PSPK 2011). Jakarta.

[BPS] Badan Pusat Statistik. 2014. Statistik Indonesia. Jakarta.

Bugiwati, S.R.A. 2007. Pertumbuhan dimensi tubuh pedet jantan sapi bali di Kabupaten Bone dan Barru Sulawesi Selatan. J. Sains and Teknol. 7(2): 103-108.

Bourdon, R.M. 2000. Understanding Animal Breeding. Prentice-Hall Inc, New Jersey.

Casas, E., S.N. White, D.G. Riley, T.P. Smith, R.A. Brenneman, T.A. Olson, D.D. Johnson, S.W. Coleman, G.L. Bennett and C.C.Jr. Chase. 2005. Assessment of single nucleotide polymorphisms in genes residing on chromosomes 14 and 29 for association with carcass composition traits in Bos indicus cattle. J. Anim. Sci. 83(1): 13-9.

Cheong, H., Du-Hak. Yoon, B.L. Park, L.H. Kim, J.S. Bae, S. Namgoong, H.W. Lee, C.S. Han, J.O. Kim, Il-Cheong. Cheong and H.D. Shin. 2008. A single nucleotide polymorphism in CAPN1 associated with marbling score in Korean cattle. BMC Genetics. 9:33

Dear, T.N., N.T. Meier, M. Hunn and T. Boehm. 2000. Gene structure, chromosomal localization, and expression pattern of Capn12, a new member of the calpain large subunit gene family. Genomics. 68: 152160.

Deaton, A.V.W. and G. Rouse. 2000. USOFT: An ultrasound image analysis software for beef quality research. Beef research report. A.S. Leaflet R1437. Iowa University.

Felicio, A.M., C. Boschiero, J.C.C. Balieiro, M.C. Ledur, J.B.S. Ferraz, T.M. Filho, A.S.A.M.T. Moura, and L.L. Coutinho.
2012. Identification and association of polymorphisms in CAPN1 and CAPN3 candidate genes related to performance and meat quality traits in chickens. Genetics and Molecular Research. 12(1): 472-482.

Gandolfi, G., L. Pomponio, P. Ertbjerg, A.H. Karlsson, L.N. Costa, R. Lametsch, V. Russo and R. Davoli. 2011. Investigation on CAST, CAPN1 and porcine gene polymorphisms and expression in relation to post-mortem calpain activity in muscle and meat quality. Meat Sci. 88: 694-700.

Goll, D.E., V.F. Thompson, R.G. Taylor, and J.A. Christiansen. 1992. Role of the calpain system in muscle growth. Biochem. J. 74: 225-237.

Hall, T.A. 1999. BioEdit: a user-friendly biological sequence alignment editor and analysis program for Windows 95/98/NT. Nucl Acids Symp. Ser. 41: 95-98.

Hou, G., H. Meng, G. Xue, L. Junya, G. Huijiang, R. Hongyan, and X. Shangzhong. 2011. Association of Calpain 1 (CAPN1) and HRSP12 allelic variants in beef cattle with carcass traits. Afr. J. Biotechnol. 10(63): 13714-13718.

Killerfer, J. and M. Koohmaraie. 1994. Bovine Skeletal Muscle Calpastatin: Cloning, Sequence Analysis, and Steady-State mRNA Expression. J. Anim Sci. 72:606614.

Li, J., Zhang, Q.F. Gan, J.Y. Li, H.J. Gao, Z.R. Yuan, X. Gao, J.B. Chen and S.Z. Xu. 2010. Association of CAST gene polimorphisms with carcass and muat quality Straits in Chinese Commercial cattle herds. Asian-Aust J. Anim. Sci. 11(23):1405-1411.

Li, X., M. Ekerljung, K. Lundstrom and A. Lunden. 2013. Association of polymorphisms at DGAT1, leptin, SCD1, CAPN1 and CAST genes with color, marbling and water holding capacity in meat from beef cattle populations in Sweden. Meat Sci. 94: 153-158.

Nei, M. and S. Kumar. 2000. Molecular Evolution and Phylogenetics. New York (US): Oxford Univ Pr.

Noor, R.R. 2008. Genetika Ternak. Penebar swadaya. Jakarta.

Martojo, H. 2003. Indigenous bali cattle: the best suited cattle breed for sustainable smal farms in Indonesia. Chinese Society Anim Sci. 21-35. 
Melendez, L.J. and J.A. Marchello. 2014. The efficacy of ultrasound to determine certain carcass traits in Grains-fed beef cattle. Inter $\mathrm{J}$ of Sci Commerce and Humanities. 2(6): 145-154.

Purwantara, B., R.R. Noor, G. Anderson and H. Martinez. 2012. Banteng dan sapi bali di Indonesia: status and forecasts. J. Reprod. Domest. Anim. 14(1):37-41.

Pinto, L.F.B., J.B.S. Ferraz, F.V. Meirelles, J.P. Eler, F.M. Rezende, M.E. Carvalho, H.B. Almeida and R.C.G. Silva. 2010. Association of SNPs on CAPN1 and CAST genes with tenderness in Nellore cattle. Genet. Mol. Res. 9(3): 1431-1442.

Raymond, M. and F. Rousset. 2001. Genepop (3.3). Population Genetics Software for Exact Tests and Ecumenicism (EB/OL) (http:www:wbiomed.curtin.edu.an/genepop).

SAS Institute Inc. 2008. SAS/STAT ${ }^{\circledR} 9.2$ User's Guide The GLM Procedure (Book Excerpt). Carolina (US): SAS Institute Inc. SAS Campus Drive.

Schwerin, M., G. Brockmann, J. Vanselow and H.M. Seyfert. 1995. Perspectives of molecular genome analysis in livestock improvement. Archiv Tierzucht. 38: 21-31.

Silva, S.L., J.U. Tarouco, J.B.S. Ferraz, R. da C Gomes, P.R. Leme and E.A. Navajas. 2012. Prediction of retail beef yield,trim fat and proportion of high-valued cuts in Nellore cattle using ultrasound live measurements. R. Bras. Zootec. 41(9): 2025-2031.
Soller, M. 1994. Marker assisted selection - an overview. Anim. Biotechnol. 5: 193-207.

Talib, C. 2002. Sapi Bali di daerah sumber bibit dan peluang pengembangannya. Wartazoa. 12(3): 100-107.

Tamura, K., D. Peterson, N. Peterson, G. Stecher, S. Nei and M. Kumar. 2011. MEGA5: molecular evolutionary genetics analysis using maximum likelihood. evolutionary distance. and maximum parsimony methods. Mol. Biol. Evol. 28(10): 27312739.

Te Pas, M.F.W., M.E. Everts and H.P. Haagsman. 2004. Muscle Development of Livestock Animals: Physiology, Genetics, and Meat Quality. CABI, UK.

Ulum, M.F., E. Suprapto and Jakaria. 2014. Citra ultrasonografi otot punggung (longissimus dorsi) pada sapi bali. Proceeding. Konverensi Ilmiah Veteriner Nasional ke13 Perhimpunan Dokter Hewan Indonesia (PDHI), 2014 Nov 23-26, Padang : KIVNAS PHDI XII. 368-369.

$\mathrm{Xu}, \mathrm{Y}$. and R.L. Mellgren. 2002. Calpain inhibitor decreases the growth rate of mammalian cell colonies. J. Biol. Chem. 277(24): 21474-21479.

Zhang, Z., Q. Zhu and Y. Liu. 2007. Correlation analysis on single nucleotide polymorphism of CAPN1 gene and meat quality and carcass traits in chickens. Sci. Agric. in China. 6(6): 749-754. 